\title{
Hydrological and economic effects of oil palm cultivation in Indonesian peatlands
}

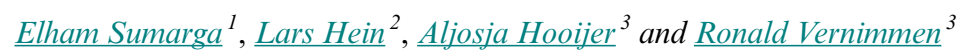

\begin{abstract}
Oil palm has increasingly been established on peatlands throughout Indonesia. One of the concerns is that the drainage required for cultivating oil palm in peatlands leads to soil subsidence, potentially increasing future flood risks. This study analyzes the hydrological and economic effects of oil palm production in a peat landscape in Central Kalimantan. We examine two land use scenarios, one involving conversion of the complete landscape including a large peat area to oil palm plantations, and another involving mixed land use including oil palm plantations, jelutung (jungle rubber; (Dyera spp.) plantations, and natural forest. The hydrological effect was analyzed through flood risk modeling using a high-resolution digital elevation model. For the economic analysis, we analyzed four ecosystem services: oil palm production, jelutung production, carbon sequestration, and orangutan habitat. This study shows that after 100 years, in the oil palm scenario, about $67 \%$ of peat in the study area will be subject to regular flooding. The flood-prone area will be unsuitable for oil palm and other crops requiring drained soils. The oil palm scenario is the most profitable only in the short term and when the externalities of oil palm production, i.e., the costs of $\mathrm{CO}_{2}$ emissions, are not considered. In the examined scenarios, the social costs of carbon emissions exceed the private benefits from oil palm plantations in peat. Depending upon the local hydrology, income from jelutung, which can sustainably be grown in undrained conditions and does not lead to soil subsidence, outweighs that from oil palm after several decades. These findings illustrate the trade-offs faced at present in Indonesian peatland management and point to economic advantages of an approach that involves expansion of oil palm on mineral lands while conserving natural peat forests and using degraded peat for crops that do not require drainage.
\end{abstract}

Key Words: ecosystem services; flood risk modeling; Indonesia; jelutung; oil palm; peat

\section{INTRODUCTION}

Indonesian peatlands are subject to rapid land cover change with significant national and global implications. The peatland area in Indonesia is estimated to be around 20 million ha (Wahyunto et al. 2004, Page and Banks 2007), and more than half of this area has been converted or degraded (Miettinen et al. 2012). Conversion of peatlands, in particular to oil palm and Acacia plantations, is still ongoing (Gunarso et al. 2013). The environmental effects of peat degradation and conversion have been published in a range of studies (Hooijer et al. 2012, SchrierUijl et al. 2013, Varkkey 2013). One of the concerns is that most plantation crops including oil palm and Acacia require drainage, affecting water levels not only in converted areas but also in surrounding peatlands (DID Sarawak 2001, Hooijer et al. 2012). Drainage of peat leads to high $\mathrm{CO}_{2}$ emissions; in degraded peatland that was drained but not converted to agriculture, carbon losses up to $463 \mathrm{Mg}$ (megagram) $\mathrm{C} /$ ha in the first 15 years following drainage have been reported by Hooijer et al. (2014); emissions are higher in agricultural areas that have lower water tables. Degradation of peat forests also leads to around $50 \%$ increase in the run-off of fluvial organic carbon (Moore et al. 2013). In addition, drained and degraded peatlands burn on a regular basis, causing air pollution and smog at distances of hundreds of kilometers (He et al. 2010). The degradation of peatlands has important consequences for biodiversity, with most of the last refugia for, for instance, orangutans found in the remaining peat forests (Yule 2010, Posa et al. 2011). Finally, a range of social issues have been reported in relation to the largescale conversion of peat areas to plantations; major issues include the loss of access to land for various uses and uneven distribution of economic benefits (Obidzinski et al. 2012, Schrier-Uijl et al. 2013).

An aspect of peat conversion that has received less attention to date, at least in a South East Asian context, is that peat drainage leads to soil subsidence. Peat consists of some $90 \%$ water; hence, besides leading to more rapid discharge and potentially increased flood risk downstream, drainage also leads to compaction of peat, causing a subsidence of typically between 1 and $1.5 \mathrm{~m}$ in the first years after drainage. Subsequently, drained peat will oxidize, causing subsidence because of a loss of organic matter by 3 to 5 $\mathrm{cm}$ per year (Wösten et al. 1997, Hooijer et al. 2012, Couwenberg and Hooijer 2013). These processes occur worldwide in peat and have been described in a range of publications (Gambolati et al. 2006, Leifeld et al. 2011, Pronger et al. 2014). Peat in tropical countries experiences higher oxidation rates than in temperate countries because the oxidation rate increases with temperature (Andriesse 1988, Couwenberg et al. 2010, Hooijer et al. 2014). Drained peatlands are, over time, likely to become subject to flooding, either by inflow of river or sea water, or from rainwater that cannot be easily discharged from the area by gravity because gradients are too low. As soon as peat is prone to floods, it becomes less suitable or, depending upon drainage levels, unsuitable for growing either oil palm or Acacia. Technically, it is possible to pump excess water out of the plantations once surface gradients have become too low for gravity drainage, but this involves very high costs compared with the revenues from agricultural land uses (Roggeri 1995, Lim et al. 2012).

\footnotetext{
${ }^{1}$ School of Life Sciences and Technology, Institut Teknologi Bandung, ${ }^{2}$ Environmental System Analysis Group, Wageningen University, ${ }^{3}$ Deltares
} 
Recent years have seen an increasing conversion of peatlands to plantations, in particular oil palm. There is currently a discussion in Indonesia on promoting biofuel production using palm oil, which could further increase land use change in peatlands. The hydrological and long-term economic effects of current peat management practices appear to be insufficiently considered in this debate. The effects of peat soil subsidence are going to be very large for Indonesia, potentially rendering millions of hectares of land unproductive in the country. However, studies of the issue are scarce, which may be related to a lack of reliable data, for instance on peat surface elevation and thickness, and land use in peat areas. Moreover, the most severe effects of peat subsidence will occur in a time frame of several decades up to a century, perhaps leading to the perception that this is not an urgent issue. However, peat subsidence is irreversible, and decisions on land use made today will have consequences for the coming decades to centuries.

The objective of this paper is to examine the effects of peat subsidence on the potential of land to sustain ecosystem services including palm oil production. We studied part of the Ex-Mega Rice Project (EMRP) area: a large, failed agricultural development project in Central Kalimantan, for which detailed elevation, peat, and economic data are available. We analyzed peat elevation, subsidence, and flood risks at present and in the future as a function of land management taking a long-term (up to 100 years) perspective. We developed two scenarios to compare different management options: (1) conversion of the whole area to oil palm plantations involving drainage of all the peatlands in the area and (2) a mixed land use scenario involving protection of currently remaining peat forests, oil palm on mineral land and in areas that are currently intensively drained, and jelutung (Dyera spp.) plantation forest on the rest of the peatlands. We selected the first scenario to elicit the potential effects of the main type of land use change ongoing in Kalimantan's peatlands at present, the conversion of peatlands to estate crops requiring drainage, in particular oil palm. Oil palm represents one of the most profitable land uses on peat (Sheil et al. 2009), and applications for new licenses to grow oil palm cover an extensive part of Indonesia including many peat areas (Murdiyarso et al. 2011). We based our second scenario on a detailed land use planning study that was undertaken in the case study area from 2007 to 2008, using jelutung as one of the most profitable species that can be grown on undrained peat (Poesie et al. 2011, Budiningsih and Effendi 2013). We included both private benefits (crop production) and social benefits (orangutan habitat and reduced carbon emissions) in the cost-benefit comparison and specifically studied the longterm effects of peat subsidence following drainage and how this will affect the costs and benefits of land use in the two scenarios. We acknowledge that we only included part of the overall costs and benefits of land use change in our analysis, and we come back to the simplifications of our valuation approach in the Discussion section.

This work complements previous work where we looked at effects of land use change in peatlands on supply of ecosystem services but did not examine the effects of soil subsidence (Sumarga and Hein 2014, Sumarga et al. 2015, Sumarga and Hein 2016). Our results are innovative in their integration of a flooding model for tropical peatlands with an economic analysis, focusing on an important but insufficiently studied type of land use change. The paper elicits the difficulties of maintaining production over the long term in drained peat areas and has important consequences for today's choices regarding land use in peatlands.

\section{METHODS}

\section{Study area}

Our case study area covers Block A and Block B of the EMRP area in Central Kalimantan, Indonesia, on the island of Borneo, in total about 490,000 ha, of which $62 \%$ is peatland. The Mega Rice Project was initiated in 1995 to convert about one million hectares of peat and lowland swamp forest into paddy rice cultivation. The project was formally terminated in 1999 in recognition of the difficulties associated with promoting rice production in the infertile and difficult-to-manage soils in the area. The area has been mostly deforested now, and most of the peat is drained by canals and subject to frequent fires (van der Meer and Ibie 2009). Figure 1 presents the location and forest coverage of Block A and Block B of the EMRP area.

Fig. 1. Block A and Block B of the Ex Mega Rice Project (EMRP) and their forests coverage (green). The forest area was derived from the 2010 land cover map of the Indonesian Ministry of Forestry.

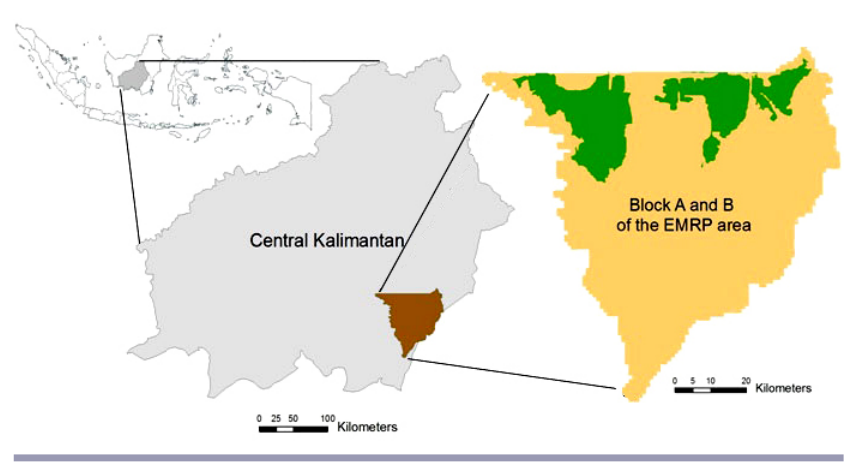

\section{Scenarios}

We compared two scenarios to assess different management options: (1) conversion of the whole area to oil palm plantations involving drainage of all the peatlands in the area and (2) a mixed land use scenario involving protection of currently remaining peat forests, oil palm on mineral land and in areas that are currently intensively drained, and jelutung plantation forest on the remaining peat area. There are at present no forests left on mineral soil in the study area. The two scenarios are described in more detail below. Given the availability of detailed hydrological and land-cover baseline data for 2011, we used 2011 as the base year of our study, even though in 2011 only a relatively small area, i.e., about 10,000 ha $(2 \%)$, in the case study area was converted to oil palm. We also use 2011 prices throughout the paper.

Oil palm $(O P)$ scenario

This scenario assumes that all peatlands, including the remaining natural peat forests, will be converted to oil palm plantation. All peat areas that are not yet drained will be drained to facilitate oil palm cultivation. All peat areas will be subject to subsidence, as explained in the next section; and over time production of oil palm fruits will decrease with increasing flood risks in the 
plantations on peat. On mineral lands, we assumed oil palm production could continue without being affected by an increase in floods. There are two potential causes of floods: floods caused by high water levels in rivers outside the plantation and inundation caused by heavy rainfall inside the plantation. Both types of flood are amplified by land subsidence: the former because the area is progressively subsiding below the high river water level, and the latter because the natural discharge of the rainfall is reduced as canal gradients decrease. We assumed that flood control to mitigate flood risks is not economically feasible when drainage by gravity alone no longer suffices. We come back to this assumption in the Discussion section.

\section{Mixed land use scenario (MIX scenario)}

This scenario assumes that the remaining natural peat forests will be maintained, and oil palm will only be established in mineral soils and in currently heavily drained areas. The remaining peat area will be developed into Jelutung plantation forest, producing timber and latex. We based this scenario on a detailed land use planning study that was undertaken in the case study area in the period from 2007 to 2008, involving an elaborate analysis of land suitability and land use options to balance production and sustainability concerns in the land use of the EMRP area (Euroconsult Mott MacDonald and Deltares 2008). A range of paludiculture crops can be grown in the peat, but for reasons of simplicity we selected jelutung for our scenario analysis. Jelutung is one of the most profitable species that can be grown on undrained peat (Poesie et al. 2011), and it is locally grown and marketed in the case study area (Budiningsih and Effendi 2013). We assumed that jelutung can be grown in undrained conditions, which may require making small ridges or mounds for the plants when planted in the wettest areas (van Wijk 1950). However, under conditions of near-permanent inundation (more than 6 months per year), jelutung cultivation would in the long term no longer be possible because seedlings cannot survive anymore. In recognition of Central Kalimantan's importance for the orangutan (around $50 \%$ of the remaining global population of wild orangutans occurs in this province) and the presence of an orangutan release area managed by the nongovernmental organization Borneo Orangutan Survival Foundation in this area, we also considered orangutan habitat as an ecosystem service provided by the remaining forests in the area. In the second scenario we assumed, based on the aforementioned land use plan, that outside of the peat areas that are now intensively drained and would be converted to palm oil, no further peat subsidence or increase in flood risks will tak place. The land use map of this scenario, derived from the 2010 land-cover map of the Indonesian Ministry of Forestry and the master plan for the rehabilitation of the EMRP, is presented in Figure 2.

\section{Flood-risk modeling}

A digital elevation model (DEM) was created using airborne Light Detection and Ranging (LIDAR) data collected in Central Kalimantan in 2011, from which the minimum value in a $25-\mathrm{m}$ window was selected as representing the peat surface (Fig. 3). The peat extent was derived from the Puslitanak map of 2004 (Wahyunto et al. 2004). The availability of this data makes it possible to create subsidence/flood-risk models for the area by applying subsidence rates known from literature.
Fig. 2. Land use map of the mixed land use (MIX) scenario, derived from the spatial zoning of master plan for the rehabilitation and revitalization of the Ex Mega Rice Project area (Euroconsult Mott MacDonald and Deltares 2008).

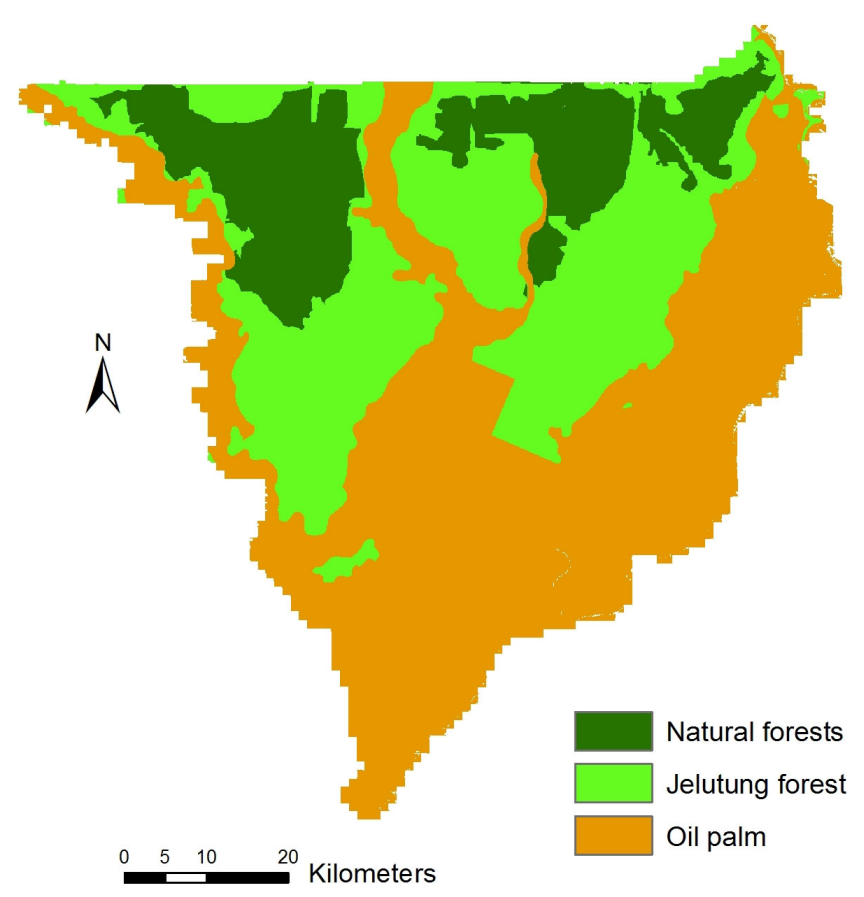

Fig. 3. Peat surface elevation (in meters above mean sea level) map for the Ex Mega Rice Project (EMRP) Blocks A and B derived from Light Detection and Ranging flown in 2011 (processed by Deltares in 2012). Nonpeat areas are masked out using the Puslitanak peat extent map (Wahyunto et al. 2004).

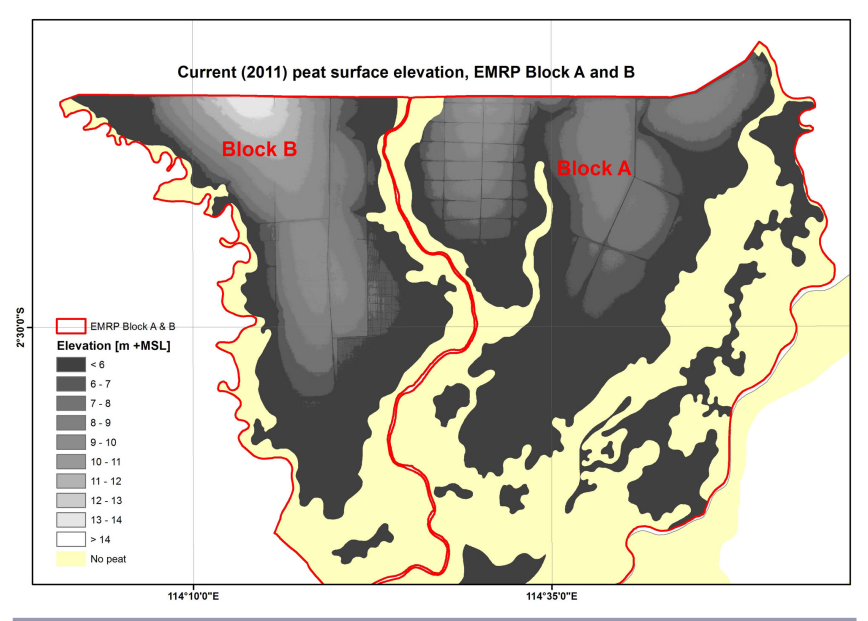

We developed a flood-risk model for the Block A and B peatland in the EMRP area, which includes parts of three separate peat domes, assuming that the area is fully developed into oil palm plantations and drained, by the year 2011 (for which we have 
elevation and land cover data). Flood risks were modeled annually for 125 years (six production cycles of oil palm production; Fairhurst and McLaughlin 2009) by taking into account three different drainage limits. Around $60 \%$ to $70 \%$ of the area was drained already by 2015 , as a consequence of the construction of canals in the area in the 1990s (Fig. 4). These canals were dug originally to assist with water management for agricultural purposes. The Mega Rice Project aimed to grow over a million hectares of rice, but this failed due to a combination of peat soil not being suitable, fires, and flooding.

Fig. 4. Canal outline in the Ex Mega Rice Project Blocks A and B peatland areas.

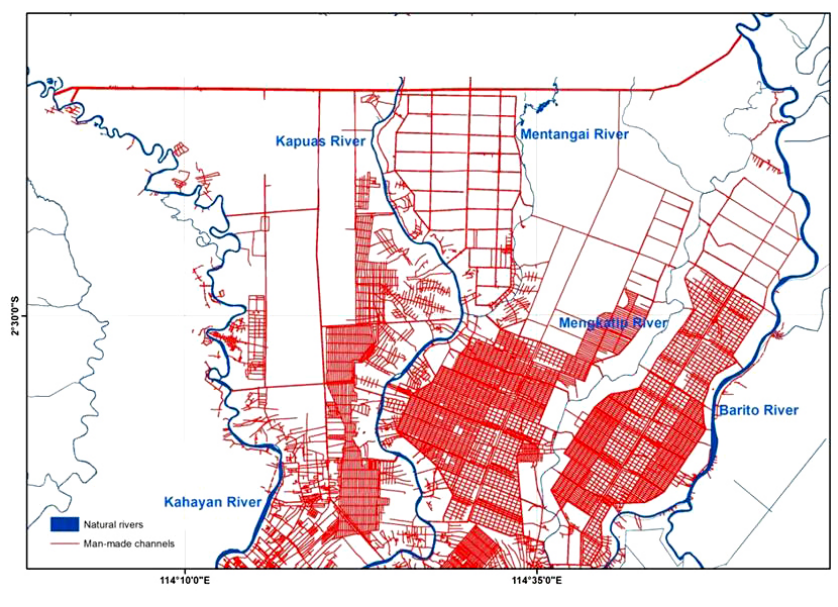

Peatland drainage is mostly controlled by water levels in local rivers, which are usually around 1-2 $\mathrm{m}$ and 2-4 $\mathrm{m}$ above mean sea level in the dry and wet periods, respectively, depending on river discharge rates and distance from the sea. To predict when peatland drainage would be inhibited by subsidence, and to what extent this would affect land use options, we used the following three drainability thresholds (Deltares 2015):

1. Impaired drainability. When the peat surface approaches the local free drainage limit (FDL), defined by adding a conveyance gradient (DID Sarawak 2001) of $0.2 \mathrm{~m} / \mathrm{km}$ to high water level (HWL) with distance from the river, drainage will be impaired and cultivation will require increased water management efforts. A soil depth of $0.5 \mathrm{~m}$ above the water table is added to FDL levels, which is the minimum required to grow crops on peatland.

2. Annual prolonged flooding. This will become inevitable when the peat surface subsides to the HWL that occurs throughout much of the tropical wet season, the minimum value of which we determined from the elevation of river levees.

3. Near-permanent inundation. Once subsidence lowers the peat surface to the low water level (LWL) that occurs in rivers during the tropical dry season, the peat surface will be inundated almost permanently (more than 6 months per year). Subsidence rates will be reduced at this stage because of waterlogging and it is uncertain if the peat surface will drop further to mean sea level.
For LWL and HWL we used $1.5 \mathrm{~m}$ and $3.5 \mathrm{~m}$, respectively, based on field observations. To estimate how long it would take for peat surface levels to subside below the drainability thresholds, subsidence rates known from literature $(3.5 \mathrm{~cm} /$ year; Deltares 2015) were applied to the data on peat surface elevation and peat thickness. For those areas that were still forested in 2010 (Fig. 1), a higher initial subsidence of on average $28 \mathrm{~cm} /$ year over the first 5 years was applied (Andriesse 1988, Wösten et al. 1997, DID Sarawak 2001, Hooijer et al. 2012). This initial subsidence was however only applied to those forested areas more than $2.5 \mathrm{~km}$ from a canal, because around existing canals some of this initial subsidence will already have taken place. Whenever the forest was closer to a canal, a linear relationship was used, being $0 \mathrm{~cm} /$ year in 5 years at $0 \mathrm{~m}$ from the canal and $28 \mathrm{~cm} /$ year during 5 years at $2.5 \mathrm{~km}$ from the canal. The canal outline is shown in Figure 4.

\section{Ecosystem services supply in the two scenarios}

We examined three ecosystem services (fresh fruit bunches [FFBs]/ FFB production of oil palm, latex and timber production from jelutung, and orangutan habitat) and one ecosystem disservice (carbon emissions) for the two scenarios specified above and for the four plantation cycles covered by the hydrological model (2011, after 25 years, after 50 years, and after 100 years). These services are described below. We realize that there are more ecosystem services generated in the study area, e.g. rattan and wood production, but for reasons of simplicity we restricted ourselves to the most economically important ones in the study area (Sumarga and Hein 2014, Sumarga et al. 2015).

Oil palm (fresh fruit bunches) production

We calculated the annual revenues from producing FFB of oil palm, and the net present value (NPV) of the expected income flow, both for oil palm in mineral soil and on peat with different flood levels. For the NPV calculation, we used a plantation cycle of 21 years with an average yield of $19 \mathrm{Mg} \mathrm{FFB} / \mathrm{ha} /$ year (based on Fairhurst and McLaughlin, 2009) and a discount rate of $10 \%$ (based on the average interbank lending rate and inflation rate of 2009-2011; see Sumarga et al. 2015). We assumed an FFB price of $€ 130$ per $\mathrm{Mg}$ FFB (average 2010-2012, derived from Kalimantan-news 2011 and Central Kalimantan Estate Agency 2012). Given the strong fluctuations in FFB prices we have taken the average over a three-year period to reduce the effects of these fluctuations. We included in our calculations land lease costs of $€ 342 / \mathrm{ha}$, reflecting the costs of acquiring land and various fees for permits and licenses, based on Boer et al. (2012). For reasons of simplicity, we assumed constant prices for production costs and FFB. We also assumed a constant yield for the first three plantation cycles and a $20 \%$ yield increase for the next three plantation cycles because of the use of enhanced varieties (based on Fairhurst and McLaughlin 2009). We come back to our assumptions in the Discussion section.

We also analyzed how oil palm FFB production will decline with increasing flood risks. The effect of flooding on oil palm productivity is considerable. Prolonged floods of weeks to months can cause mortality of mature trees (Abram et al. 2014). Physiologically, in waterlogged soil conditions, soil pores become water filled, leading to several major problems for the plant such as oxygen and nutrient deficits (Colmer and Voesenek 2009). Seedlings and young plants are especially vulnerable (Hai et al. 2001, Dewi 2009, Holidi et al. 2014). Ahamad et al. (2009) found 
in Malaysian oil palm plantations that a flood of 7 days at $25 \mathrm{~cm}$ already leads to a productivity loss of $20 \%$. An FFB production drop of about $30 \%$ was reported by Sabari et al. (2014) because of flood events in a Malaysian plantation in 2008. Prolonged floods may also cause physical damage to trees (toppling over), causing permanent production losses from affected trees. Based on these estimates, we conservatively assumed a production loss of $25 \%$ in the case of impaired drainability, of $50 \%$ in the case of annual prolonged flooding, and of $100 \%$ in the case of nearpermanent inundation. We acknowledge the uncertainty in these assumptions and carried out a sensitivity analysis, as reported in the Discussion section. We assumed that production of FFB would stop as soon as the NPV turns negative.

\section{Jelutung production}

We calculated the annual yields and the NPV of jelutung production based on Harun (2011). We used a production cycle of 30 years and a discount rate of $10 \%$. The production includes latex production during years 10 to 30 and timber production at the end of year 30. We also included land lease costs of $€ 342$ as used for oil palm. We assumed that jelutung is developed in a monoculture system. In line with the NPV calculation for FFB production, we also used constant (2011) prices for latex and production costs.

\section{Carbon emissions}

For carbon sequestration and emissions, we calculated the flow of carbon, expressed on a per hectare per year basis, and the NPV of these flows in four land use types: oil palm on peat, oil palm on mineral soil, natural peat forest, and Jelutung forest. Oil palm development on peat requires continuous peat drainage, resulting in high carbon emissions. We used an estimate of carbon emissions of $15 \mathrm{Mg} \mathrm{C} / \mathrm{ha} /$ year for oil palm on peat with a water table depth of $50 \mathrm{~cm}$ (derived from Hooijer et al. 2012). The 50 $\mathrm{cm}$ drainage for oil palm is best environmental practice and is the drainage depth promoted by sustainability initiatives in the sector (Ministry of Agriculture 2011, Lim et al. 2012); however, in practice drainage depths in plantations in peat often exceed 50 $\mathrm{cm}$ (Couwenberg and Hooijer 2013). Hence, our assessment in this regard is conservative. For oil palm on mineral soil, the carbon balance depends on the previous land cover types converted to oil palm. We used an average carbon sequestration of $1.9 \mathrm{Mg} \mathrm{C} /$ ha/year, based on an average estimate of Germer and Sauerborn (2008), assuming that the plantation was established in a nonforested area and excluding carbon emissions from land clearing.

There are no specific data on carbon sequestration or emissions in jelutung plantations, and we assumed that these are equal to the rates in secondary forest, given that the jelutung trees become quite large and resemble natural forest trees in the study area (their latex is tapped in the lower parts of the stem). For undrained conditions we assumed, based on the estimates of Suzuki et al. (1999) for carbon sequestration in protected, undrained peat swamp forest, that the sequestration amounts to $5.3 \mathrm{Mg} \mathrm{C} / \mathrm{ha} /$ year. For lightly to moderately drained secondary forest in peat, carbon emissions of $7.9 \mathrm{Mg} \mathrm{C} /$ ha/year have been estimated by Hooijer et al. (2014). We assumed that these emissions also occur in the drained jelutung plantations and drained forests in our study area.
The monetary value of carbon sequestration and the costs of carbon emissions were based on the Social Costs of Carbon (SCC) estimated by the United States Environmental Protection Agency (2013). The used value is USD $\$ 39$ per milligram of $\mathrm{CO}_{2}$, which is equivalent to $€ 28$ per $\mathrm{Mg} \mathrm{CO}_{2}(€ 103 / \mathrm{Mg} \mathrm{C})$ with an average 2011 exchange rate of $\$ 1.39$ for $€ 1$. Acknowledging that the SSC is calculated using a social discount rate (in the case of the value we used 3\%), we nevertheless used a discount rate of $10 \%$ and a 21-year discounting period to analyze the NPV of the benefits of carbon sequestration and the costs of emissions to be aligned with the NPV calculations for our other ecosystem services. If we would have used a lower discount rate and a longer discounting period to calculate the NPV, both the social costs of the carbon emissions and the social benefits from carbon sequestration would have been markedly higher. Because of high carbon emissions in the oil palm scenario, this would have favored the mixed land use scenario.

\section{Orangutan habitat}

Finally, we also assessed orangutan (Pongo pygmaeus) habitat maintained in this scenario based on an orangutan habitat suitability map (Sumarga and Hein 2014). The orangutan is an endangered species, and Central Kalimantan has the world's largest population of orangutans at the provincial level (Wich et al. 2008). We analyzed this service only in physical quantity, given the difficulties with monetary valuation of aspects of biodiversity (cf., Sumarga et al. 2015). We used hectare of orangutan habitat as the indicator for this service, with orangutan habitat consisting of, in general terms, forests with a well preserved crown cover with overlapping branches to allow the animals to migrate within the forest, and not heavily influenced by disturbances from villages or roads. We analyzed the suitability for orangutan habitat in the study area based on data from Sumarga and Hein (2014). In general, orangutan habitat translates to orangutan numbers in the sense that the density of the species is, on average, one individual per 100 ha. However, numbers can be higher or lower depending upon food availability and/or on the presence of orangutans fleeing from other areas or released in the area.

\section{RESULTS}

\section{Flood risk maps}

Figure 5 shows the four flood risk maps that present the modeled flood conditions in 2011 and after 25, 50, and 100 years of subsidence in case of the OP scenario. For our analysis, we calculated flood maps for every year (until 125 years after drainage) because we related palm oil production to flood conditions occurring in each year for which the NPV of palm oil production was calculated. Figure 5 shows that under current (2011) conditions considerable areas already are subject to drainage problems under the FDL drainability threshold (impaired drainability), whereas currently no flooding problems exist at the LWL drainage limits (near-permanent inundation). Near-permanent drainage problems (LWL threshold) start for small areas in 25 years, whereas in 100 years' time some $46 \%$ of the peat area will be subject to near-permanent inundation. Details about the flooded areas in each year are presented in Table 1. 
Table 1. Flooded areas (hectares) for each drainage limit under current (2011) condition and after 25, 50, and 100 years under two land use scenarios (oil palm and mixed land use); areas are rounded to thousand hectares.

\begin{tabular}{|c|c|c|c|c|c|}
\hline Scenario & Flood level & 2011 & After 25 years & After 50 years & After 100 years \\
\hline \multicolumn{6}{|l|}{ Oil palm } \\
\hline Oil palm on mineral soil & No flooding & 193,000 & 193,000 & 193,000 & 193,000 \\
\hline \multirow[t]{4}{*}{ Oil palm on peat } & No flooding & 168,000 & 134,000 & 103,000 & 36,000 \\
\hline & Impaired drainability & 80,000 & 53,000 & 52,000 & 63,000 \\
\hline & Frequent flooding & 53,000 & 113,000 & 110,000 & 64,000 \\
\hline & Near-permanent inundation & 0 & 1000 & 36,000 & 138,000 \\
\hline \multicolumn{6}{|c|}{ Mixed land use (based on Euroconsult MacDonald and Deltares 2008) } \\
\hline Natural forest & No flooding ${ }^{\dagger}$ & 84,000 & 84,000 & 84,000 & 84,000 \\
\hline Jelutung forest & No flooding ${ }^{\dagger}$ & 156,000 & 156,000 & 156,000 & 156,000 \\
\hline Oil palm on mineral soil & No flooding & 193,000 & 193,000 & 193,000 & 193,000 \\
\hline \multirow[t]{4}{*}{ Oil palm on peat } & No flooding & 1000 & 0 & 0 & 0 \\
\hline & Impaired drainability & 23,000 & 1000 & 0 & 0 \\
\hline & Frequent flooding & 37,000 & 58,000 & 34,000 & 0 \\
\hline & Near-permanent inundation & 0 & 2000 & 27,000 & 61,000 \\
\hline
\end{tabular}

${ }^{\dagger}$ Assuming that there is no further peat subsidence in jelutung and natural forests. If subsidence occurs, for some currently drained areas some degree of hydrological restoration may be required. Costs of restoration are not included in the analysis. Note also that a minor part of the jelutung forest is subject to impaired drainability and prolonged flooding but because jelutung is assumed to tolerate such levels of flooding, these are classified as having no flooding.

Fig. 5. Flood risk maps for the Ex Mega Rice Project Blocks A and $\mathrm{B}$ peatland areas. Blocks $\mathrm{A}$ and $\mathrm{B}$ peatland areas under (a) current (2011) conditions and after (b) 25, (c) 50, and (d) 100 years of subsidence applying the free drainage limit, high water level, and low water level drainage limits for the oil palm scenario.

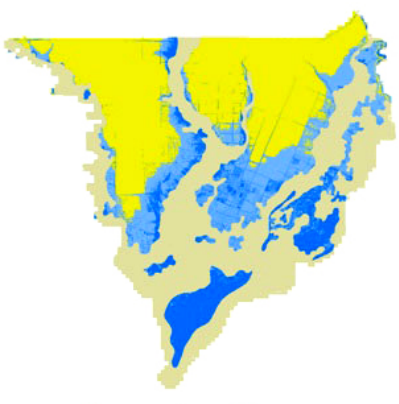

a. under current conditions

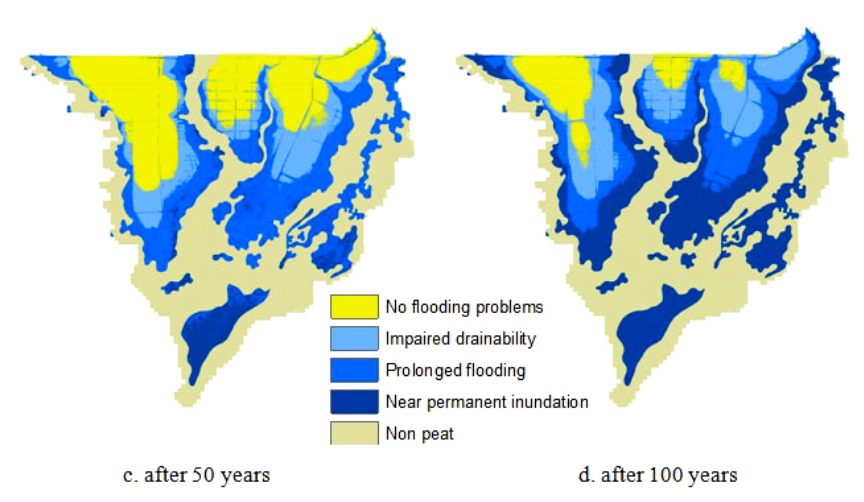

\section{Ecosystem services production}

Oil palm production

A cash flow analysis in line with the assumptions specified above, including costs of land lease, costs of intermediate consumption, labor, and the user costs of produced assets (depreciation and capital use costs), shows that, for one plantation cycle in the first three plantation cycles, the NPV of FFB production is $€ 7295$ for oil palm on mineral soil (Appendix 1, Table A 1.1) and $€ 5104 /$ ha for oil palm on peat (under no-flooding conditions for the entire period of a plantation cycle, see Table A 1.2). After 100 years, with the assumed yield increase described in the Methods section, the NPV for a 21-year plantation cycle is $€ 10,903$ for oil palm production on mineral soil and $€ 8712$ for production on peat. Based on the assumptions on production loss described in the Methods section, the NPV of FFB production under impaired drainability is drastically reduced, to only $€ 593$ per hectare, and the NPV is 0 for areas under near-permanent inundation and under prolonged flooding conditions. Hence, in our model, oil palm plantations will be abandoned by the time floods reach nearpermanent inundation and profits are very low under the impaired drainability condition. In practice, companies may start abandoning plantations already under the impaired drainability condition given that the low NPV per hectare leads to a very low return on capital invested for the companies involved. Table A 1.3 provides the NPV of FFB production when flood risks change within a plantation cycle.

\section{Jelutung production}

We used the costs and revenue of a monoculture jelutung production provided by Harun (2011) and modified the NPV calculation with a discount rate of $10 \%$, resulting in an NPV of $€ 3887 /$ ha. This NPV includes the revenue from timber harvest in the last year of the production cycle (30 years). The average jelutung production is $4.7 \mathrm{Mg} / \mathrm{ha} /$ year for latex production and $10.7 \mathrm{~m}^{3} /$ ha/year for timber production. Detailed calculations of the NPV of jelutung production are presented in Table A1.4. This 
Table 2. Implications of two land use scenarios (OP and MIX) on ecosystem services, in terms of physical units and net present value (NPV).

\begin{tabular}{|c|c|c|c|c|c|c|c|c|}
\hline \multirow{2}{*}{$\begin{array}{l}\text { Scenario } \\
\quad \text { Period }\end{array}$} & \multicolumn{2}{|c|}{ Oil palm production $^{\dagger}$} & \multicolumn{2}{|c|}{ Jelutung production } & \multicolumn{2}{|c|}{ Carbon sequestration $^{\ddagger}$} & \multirow{2}{*}{ 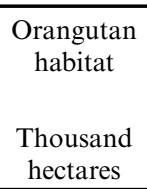 } & \multirow{2}{*}{$\begin{array}{c}\text { Total NPV }(€ \\
\text { million) }\end{array}$} \\
\hline & $\begin{array}{l}\text { Physical flow } \\
\text { (Tg FFB/year) }\end{array}$ & $\begin{array}{l}\text { NPV ( } € \\
\text { million) }\end{array}$ & $\begin{array}{l}\text { Physical flow } \\
\text { (Tg latex/year) }\end{array}$ & $\begin{array}{l}\text { NPV ( } € \\
\text { million) }\end{array}$ & $\begin{array}{l}\text { Physical flow } \\
\text { (Tg C/year) }\end{array}$ & $\begin{array}{l}\text { NPV ( } € \\
\text { million) }\end{array}$ & & \\
\hline \multicolumn{9}{|l|}{ Oil palm (OP) } \\
\hline 2011 & $\begin{array}{l}4.5 \text { (mineral) } \\
3.8 \text { (peat) }\end{array}$ & $\begin{array}{c}1863 \\
\text { (mineral) } \\
811 \text { (peat) }\end{array}$ & 0 & 0 & $\begin{array}{c}0.37 \\
\text { (mineral) } \\
-4.52 \text { (peat) }\end{array}$ & $\begin{array}{c}359 \\
\text { (mineral) } \\
-4424 \text { (peat) }\end{array}$ & 0 & -1391 \\
\hline $\begin{array}{l}\text { After } 25 \\
\text { years }\end{array}$ & $\begin{array}{l}4.5 \text { (mineral) } \\
3.0 \text { (peat) }\end{array}$ & $\begin{array}{c}1863 \\
\text { (mineral) } \\
669 \text { (peat) }\end{array}$ & 0 & 0 & $\begin{array}{c}0.37 \\
\text { (mineral) } \\
-4.52 \text { (peat) }\end{array}$ & $\begin{array}{c}359 \\
\text { (mineral) } \\
-4424 \text { (peat) }\end{array}$ & 0 & -1533 \\
\hline $\begin{array}{l}\text { After } 50 \\
\text { years }\end{array}$ & $\begin{array}{l}4.5 \text { (mineral) } \\
2.6 \text { (peat) }\end{array}$ & $\begin{array}{c}1863 \\
\text { (mineral) } \\
536 \text { (peat) }\end{array}$ & 0 & 0 & $\begin{array}{c}0.37 \\
\text { (mineral) } \\
-4.52 \text { (peat) }\end{array}$ & $\begin{array}{c}359 \\
\text { (mineral) } \\
-4424 \text { (peat) }\end{array}$ & 0 & -1666 \\
\hline $\begin{array}{l}\text { After } 100 \\
\text { years }\end{array}$ & $\begin{array}{l}4.5 \text { (mineral) } \\
1.5 \text { (peat) }\end{array}$ & $\begin{array}{c}1863 \\
\text { (mineral) } \\
276 \text { (peat) }\end{array}$ & 0 & 0 & $\begin{array}{c}0.37 \\
\text { (mineral) } \\
-4.52 \text { (peat) }\end{array}$ & $\begin{array}{c}359 \\
\text { (mineral) } \\
-4424 \text { (peat) }\end{array}$ & 0 & -1926 \\
\hline \multicolumn{9}{|c|}{ Mixed land use (MIX) } \\
\hline 2011 & $\begin{array}{c}4.5 \text { (mineral) } \\
0.1 \text { (peat) }\end{array}$ & $\begin{array}{c}1863 \\
\text { (mineral) } \\
\text { (peat) }\end{array}$ & 0.4 & 606 & $\begin{array}{c}0.37 \\
\text { (mineral) } \\
0.36 \text { (peat) }\end{array}$ & $\begin{array}{c}359 \\
\text { (mineral) } \\
349 \text { (peat) }\end{array}$ & 84 & 3183 \\
\hline $\begin{array}{l}\text { After } 25 \\
\text { years }\end{array}$ & $\begin{array}{c}4.5 \text { (mineral) } \\
0.007 \text { (peat) }\end{array}$ & $\begin{array}{c}1863 \\
\text { (mineral) } 1.1 \\
\text { (peat) }\end{array}$ & 0.4 & 606 & $\begin{array}{c}0.37 \\
\text { (mineral) } \\
0.36 \text { (peat) }\end{array}$ & $\begin{array}{c}359 \\
\text { (mineral) } \\
349 \text { (peat) }\end{array}$ & 84 & 3178 \\
\hline $\begin{array}{l}\text { After } 50 \\
\text { years }\end{array}$ & $\begin{array}{c}4.5 \text { (mineral) } \\
0 \text { (peat) }\end{array}$ & $\begin{array}{c}1863 \\
\text { (mineral) } 0 \\
\text { (peat) }\end{array}$ & 0.4 & 606 & $\begin{array}{c}0.37 \\
\text { (mineral) } \\
0.36 \text { (peat) }\end{array}$ & $\begin{array}{c}359 \\
\text { (mineral) } \\
349 \text { (peat) }\end{array}$ & 84 & 3177 \\
\hline $\begin{array}{l}\text { After } 100 \\
\text { years }\end{array}$ & $\begin{array}{c}4.5 \text { (mineral) } \\
0 \text { (peat) }\end{array}$ & $\begin{array}{c}1863 \\
\text { (mineral) } 0 \\
\text { (peat) }\end{array}$ & 0.4 & 606 & $\begin{array}{c}0.37 \\
\text { (mineral) } \\
0.36 \text { (peat) }\end{array}$ & $\begin{array}{c}359 \\
\text { (mineral) } \\
349 \text { (peat) }\end{array}$ & 84 & 3177 \\
\hline
\end{tabular}

Tg indicates teragram.

${ }^{\dagger}$ See Table A1.6 for an example of detailed calculation of the total NPV of fresh fruit bunch (FFB) production on peat under increasing flood risks in rotation 1 of the OP scenario.

* Plus (+) indicates sequestration, and minus (-) indicates emissions. Carbon emissions are expected to slow down in near-inundated conditions, but this is not accounted for in the current calculations because the slow down rate is unknown.

analysis shows that jelutung generates somewhat lower net revenues than oil palm grown on peat in no-flooding conditions. However, once the oil palm area subsides below FDL and drainage becomes impaired, the value of oil palm production becomes only about one sixth of jelutung production.

\section{Carbon sequestration}

Based on the carbon sequestration and carbon emissions data specified in the Methods section, we derived the NPV of carbon sequestration as follows: $€ 1862 /$ ha for oil palm on mineral soil, $€ 14,698 /$ ha for oil palm on peat, and on average $€ 5193 /$ ha for natural peat forest and jelutung forest (see Table A 1.5 for detailed calculations). The positive value represents sequestration, and the negative value represents emissions.

\section{Orangutan habitat}

We identified about 34,000 ha of peat forest in the study area $(40 \%$ of the remaining forest) as suitable area for orangutan habitat, based on the habitat suitability map for orangutan from Sumarga and Hein 2014. In the MIX scenario, in line with the forest protection and rehabilitation program, we assumed that because of natural regrowth, all forest area (about 84,000 ha) will become suitable for orangutan habitat. In the OP scenario, conversion of forest into oil palm plantation will remove the capacity of the area to support orangutan preservation; hence, the overall area will be unsuitable for orangutan habitat.

\section{Scenario analysis of ecosystem productivity}

Table 2 shows the benefits from different land uses in the two scenarios, analyzed for four plantation cycles of oil palm production. In scenario 1 , the social costs of carbon emissions considerably outweigh the benefits of oil palm production even at the first plantation cycle, with a total NPV of $-€ 1391$ million, confirming that growing oil palm in peat is not recommendable from an economic perspective. However, private profits in the first approximately four decades of oil palm production outweigh the profits from jelutung plantations. In the second period of our scenario analysis, the mixed land use generates a higher return for the growers of plantation crops. After two plantation cycles, oil palm production is no longer feasible because of flooding in a large part of the study area, whereas jelutung production continues without a decline in production. Timber and rattan harvesting, in the mixed land use scenario, provide additional revenue throughout the modeling period that are not included in our calculations. 
We are overestimating the benefits of the oil palm scenario by omitting two factors. First, the oil palm scenario requires important investments in currently lacking infrastructure, in particular roads, to reach the plantations. At least in part these roads would have to be constructed in peat, making them relatively expensive to construct and maintain. In the second scenario, the most inaccessible parts of the area would remain forested and much less infrastructure would be required. Second, several other products can be harvested in the forest such as rattan and mushrooms, and there may also be opportunities for ecotourism, a growing business in Central Kalimantan. Moreover, fishing is a main activity in the area, and large-scale oil plantations would, through loss of access to river and through pollution of rivers because of runoff from plantations, reduce fishing opportunities in the area.

In addition, the study area contains an orangutan release area and is bordering the Mawas forest containing around 2500-3000 orangutans or around $5 \%$ of the global total of the remaining specimens in the wild. We are not able to put a meaningful monetary value on this service, but believe that it should be an important point of consideration in deciding on land use options. Our study clearly shows the trade-off in development that Indonesia is facing regarding the use of peatlands, between shortterm profits from oil palm cultivation (1 or at most 2 plantation cycles) and long-term profits from more sustainable land use. If all peat land in the case study site would have been converted to oil palm in 2011 , only around $12 \%$ of the peat area would still be suitable (no flooding problems) for oil palm by 2111 (Table 1).

\section{DISCUSSION}

\section{Uncertainties}

Our study benefited from the availability of a high-resolution LIDAR DEM for the study area. LIDAR can be used to producing an accurate, high-resolution DEM because of its capability of canopy penetration (Liu 2008). The accuracy of a LIDAR DEM depends on the land cover types, with typical vertical uncertainty less than $30 \mathrm{~cm}$ in evergreen and deciduous forests (Hodgson and Bresnahan 2006). We believe our DEM to be relatively robust compared with other sources of uncertainty. A second potential source of uncertainty is the assumptions used for subsidence rates. Subsidence rates are based on empirical studies in Indonesia and Malaysia, with comparable peat conditions to our study area, and have been confirmed in a range of studies (Couwenberg and Hooijer 2013, Farmer et al. 2014). We are therefore confident about our assumptions in this regard. A third source of uncertainty pertains to the $\mathrm{CO}_{2}$ emission from drainage. We acknowledge the uncertainties involved and in response have selected a relatively conservative scenario, assuming that oil palm in the area will be grown under the best environmental practices promoted by the Roundtable on Sustainable Palm Oil (RSPO) and the Indonesian Sustainable Palm Oil (ISPO), i.e., $50 \mathrm{~cm}$ drainage. This, however, is not likely to occur in reality in the whole study area given the difficulties in managing water levels in Indonesian peatlands and the tendency of plantation holders in peat to drain more (to over $1 \mathrm{~m}$ depth) to reduce risks of waterlogging during the wet season (Couwenberg and Hooijer 2013). Hence we underestimate the amount of $\mathrm{CO}_{2}$ emissions, and accordingly also the subsidence rate, in particular in the OP scenario. Our model also does not account for the potential increase of sea or river level due to climate change, making this assessment even more conservative.

Our land use scenario is also a main source of uncertainty. It is clear that in 2011 not all land in the study area was converted to oil palm plantations. As shown in Figure 4, around $70 \%$ of the study area was drained by 2011 , which means that in the OP scenario, we assumed an additional drained area of around $30 \%$. Also, identified from the 2010 land cover map, only about $2 \%$ of peatland in the area was converted to oil palm in 2010, and there were no other large plantations in this year. Hence, our model strongly overestimates the total NPV generated in the study area by oil palm plantations in 2011. This also applies for the MIX scenario, where we assumed that about $20 \%$ of the peat area was developed for oil palm. The purpose of our paper was to elicit the hydrological and economic implications of potential land use decisions by comparing a scenario involving full land use change to oil palm with a more balanced mixed land use scenario.

We are aware of the limitations in our valuation approach. For instance we did not include any multiplier effects from oil palm or jelutung production, and we did not analyze potential changes in consumer surplus due to changes in market supply of palm oil or jelutung, based on our assumption that the overall effect of either scenario on global market production for both crops is very small. We also assumed that an increase in jelutung production would not lead to lower prices for producers, based on the assumption that it is produced for a global market where it competes with other rubber crops. As mentioned earlier, we included only four ecosystem services in our analysis, albeit based on our earlier work the most important ones (Sumarga et al. 2014). This means that we underestimated the total benefits of, in particular, the mixed land use scenario. For instance, some of the forested area close to rivers in the mixed land use scenario is suitable for rattan, which would yield net benefits of around $€ 30$ / ha/year (Sumarga et al. 2015). Forest timber production could lead to benefits of around $€ 28 /$ ha/year (Sumarga et al. 2015), but care needs to be taken that this would not negatively affect orangutan habitat. We were not able to quantify benefits from other services such as fish production in blocked canals or other nontimber forest products.

Other potential sources of uncertainty are the assumptions on the loss of oil palm FFB production because of different levels of flooding, the discount rates, and the prices of oil palm FFB and jelutung in the future. We assumed constant prices for both FFB and jelutung. In reality these prices will change, and changes over a period of 100 years may be considerable. For instance, we assumed an FFB price of $€ 130 / \mathrm{Mg}$ FFB (average 2010-2012), whereas the oil palm price fluctuated between 2011 and July 2015 between around $€ 110$ and $€ 150$. The effect of the uncertainties can be identified by a sensitivity analysis. We analyzed the sensitivity of the NPV of oil palm FFB production to the assumed production losses because of different types of flooding. We found a high sensitivity of the NPV of FFB production to the assumed production loss both under prolonged flooding and impaired drainability conditions. For instance, by assuming production losses in prolonged flooding areas to be $40 \%$ (instead of $50 \%$ ), the NPV of FFB production increases from $-€ 3917$ to $-€ 2113$. The NPV of oil palm grown under impaired drainability and frequent flooding would also be higher when lower production 
losses are assumed, but this would also not significantly affect the overall benefits produced in the two scenarios.

\section{Is sustainable oil palm on drained peatland possible?}

Oil palm has increasingly been established on peatland in Central Kalimantan, increasing from about 4000 ha $(1.4 \%$ of the total area of oil palm) in 2000 to 97,000 ha $(8.2 \%$ of the total area of oil palm) in 2010 (Sumarga and Hein 2014). Three reasons may contribute to the increase of oil palm expansion on peatland. First, the availability of land with mineral soil for oil palm expansions is increasingly limited. Mineral soil areas in the lowlands are preferable for oil palm cultivation because of the lower production costs (Fairhurst and McLaughlin 2009). However, because of the high competition for land, most of those areas have already been occupied by oil palm and other land uses, are unavailable because of land ownership disputes, or are too fragmented for industrial use. Second, there are relatively few people living on peatland, which reduces the chance of social conflicts in case of the conversion of peat (Casson et al. 2007). Third, some of the peat areas have forest cover remaining, and the extraction of timber from the forest provides funds for the establishment of the plantation; the same mechanism applies to oil palm establishment on mineral soil, although access to timber resources is easier on mineral soil and many of these forests have been logged in the past already (see, e.g., Fuller et al., 2004).

Efforts have been made to promote sustainable management of oil palm on peatland (Agus and Subiksa 2008, Nurida et al. 2011, Lim et al. 2012). The efforts address three main issues: yield improvement, environmental management, and local community empowerment. An aspect getting a lot of attention is how to maintain the optimum FFB production while minimizing greenhouse gas emissions. This mainly focuses on water management practices, principally by keeping the water level at $50-70 \mathrm{~cm}$ below the peat surface. This water level is still conducive to oil palm growth and production, and leads to lower fire risks and carbon emissions compared with deeper drainage levels. Our study, however, shows that even with such relatively shallow drainage (compared to current practices), $\mathrm{CO}_{2}$ emissions are still considerable, and even in this case oil palm areas will subside in an irreversible manner, to be eventually taken out of production. We refer to Sumarga and Hein (2016) for a more detailed analysis of the social costs of carbon emissions from oil palm in peat.

We assumed that flood control through pumping water out of peatlands to maintain oil palm production in the study area is not possible. Maintaining production under increased flood risks requires flood control involving an integrated system of drainage canals, dykes, pumping stations, and retention basins. Design of these elements requires considering safety levels, costs, and subsequently the optimal safety level, pump capacity, and retention capacity as a function of land use, acceptable risk levels, and local topography and hydrology (Morita 2008, Mondeel and Budinetro 2010). Applying flood control measures in tropical peat for individual blocks/plantations is very expensive because extensive stretches of dykes would be required, and because these dykes, if constructed on peat, will sink into the peat. They may also crack during periods of drought and therefore require continuous, and expensive, maintenance. Developing a "polder" system with dykes on mineral land around the peat to manage water and flood levels in the peat is also not likely to be feasible in the study area. The individual peat domes in the area are very large (several are 10,000 ha), and construction of dykes, pumping stations, canals, and water level monitoring systems would be very expensive. With an average annual rainfall in the province of about $2900 \mathrm{~mm}$ (Ichsan et al. 2013) and high rainfall intensity during extreme events, the pumping capacity required would be large and expensive. It would also require developing the institutions required for large-scale water management, which would be a major challenge in the remote study area (Louck et al. 2005).

Based on the effects of flooding on crop production options, the irreversible nature of peat subsidence, the lack of options to mitigate flood risks, and the additional risks that climate change and sea level rise pose to Indonesian lowlands, we conclude that sustainable oil palm cultivation in Indonesian peatlands is not possible. Through careful land use planning, expansion of the oil palm sector should be accommodated in mineral lands, whereas peatlands should be restored to natural conditions where needed or used for the production of crops that do not require drainage, in combination with sustainable forest management and wildlife conservation where appropriate.

\section{Policy implications}

The Indonesian government has issued four regulations directly related to oil palm development on peatland. The latest regulation is Presidential Instruction No. 8 (Republic of Indonesia 2015), which forbids both local and central governments to issue new concessions (including for oil palm) in peatland and primary forests in all kind of state lands, i.e., conservation forests, protected forests, production forests, and lands for other purposes. This moratorium is temporary and valid for two years (May 2015-May 2017) and may be extended. This regulation is an extension of Presidential Instruction No. 6 (Republic of Indonesia 2013) and Presidential Instruction No. 10 (Republic of Indonesia 2011), which regulate the same moratorium issue. Another regulation is the Ministry of Agriculture Decree No. 14 (Ministry of Agriculture 2009), guiding the use of peatland for oil palm cultivation. This regulation allows oil palm cultivation on peatland, but restricts the cultivation to land with a peat depth less than $3 \mathrm{~m}$.

In addition, and complementary to the national moratorium, the challenge to facilitate oil palm expansion while minimizing environmental degradation is also responded to by two certification schemes: the RSPO and the ISPO initiatives. Both RSPO and ISPO require compliance with national laws and regulations, including the Indonesian forest conversion moratorium policy. Several principles and criteria have been adopted by both RSPO and ISPO to promote sustainable oil palm on peatland, including minimizing soil subsidence, maintaining water quality and availability, and reducing greenhouse gas emissions. This requires a water management program that maintains the water table within a range of $50-75 \mathrm{~cm}$ below ground surface through a network of appropriate water control structures. As we analyzed, however, these recommendations are not sufficient to ensure sustainability of oil palm cultivation.

Our paper provides several potentially relevant insights for policies aimed at finding cost-effective ways to minimize peat degradation. In this context, potential options to consider are:

1. Peatland preservation. This study shows the hydrological and economic effects of draining peatlands for oil palm development. Because oil palm production in peat lands 
cannot be maintained in the medium and long term, the paper illustrates the need to stop further conversion of the remaining undrained peatlands. Continuing the moratorium on converting peatlands, or making this moratorium permanent, would contribute to arresting peat conversion and would bring a number of social benefits. For example, Sumarga and Hein (2016) showed for Central Kalimantan that a moratorium on peatland conversion up to 2025 would generate social benefits of around $€ 1470$ million/year from reduced carbon emissions compared with ongoing peat conversion.

2. Peatland restoration. Considering that many unproductive peat areas have been partly or fully drained, peat restoration programs should be initiated by rewetting actions such as canal blocking to reduce ongoing subsidence, greenhouse gas emissions, and fire risk. This can be combined with assisted natural regeneration, using species such as jelutung (Dyera spp.), Shorea balangeran, Palaquium sp., and Gonystylus bancanus in Kalimantan (Van der Meer and Ibie 2009). Pilot projects should be started to test how to most cost-efficiently restore degraded peatlands, building, among others, upon the technical designs for canal blocking developed by the Kalimantan Forest Climate Partnership project (Australia Indonesia Partnership 2009). Given the major reductions in $\mathrm{CO}_{2}$ emissions that can be achieved with peat restoration, it should be examined if and how REDD+ funding could be used to fund this.

3. Facilitating the use of "degraded land" on mineral soil for oil palm expansion. Sumarga and Hein (2014) formulate an ecosystem services approach to identify areas where palm oil expansion would not compromise the supply of key ecosystem services and identify 1.8 million ha of land available in Central Kalimantan (see also Smit et al. 2013). Given that land holdings are much more scattered in these mineral lands, the promotion of palm oil production in mineral lands may be well combined with an approach enabling smallholders to produce palm oil by providing them with technical advice, loans, high-quality seedlings, and so forth (Barlow et al. 2003, Feintrenie et al. 2010). A positive side effect would be that there would potentially be increased carbon storage if degraded lands are replaced by oil palm plantations (e.g., Germer and Sauerborn. 2008).

\section{CONCLUSIONS}

We analyzed the hydrological and economic effects of two scenarios for peatland management: a scenario involving conversion of the whole case study area of around half a million ha (of which around $60 \%$ is peatland) to oil palm (OP) and a scenario involving mixed land use with oil palm on mineral land and heavily degraded peat, combined with jelutung and forests in other peatlands (MIX). We assumed best water management practices in oil palm plantations on peat, as are currently promoted by RSPO and IPSO, and analyzed the effects of drainage on soil subsidence and, consequently, on flood risks. Three types of flood risks were modeled: impaired drainability, frequent flooding, and near-permanent inundation. We estimated the economic value generated by two ecosystem services, palm oil production and Jelutung production, and the costs associated with $\mathrm{CO}_{2}$ emissions in drained peatlands. We also estimated orangutan habitat in physical terms only as an indicator for biodiversity.

In the OP scenario, soil subsidence progressively affects the possibility to use the peat for oil palm production. In 100 years' time, around $46 \%$ of the peat in the study area will be subject to near-permanent inundation and only $12 \%$ of the peat will not be affected by floods and therefore will still be suitable for oil palm. In the OP scenario, the social costs of carbon emissions from oil palm on peat exceed the private benefits from oil palm (see Table 2), confirming the magnitude of the externalities resulting from oil palm cultivation on peat. In the MIX scenario, production of oil palm is concentrated on mineral lands, and jelutung production on peat can continue sustainably. We show that, when the costs of $\mathrm{CO}_{2}$ emissions are not considered, oil palm cultivation on peat is profitable in the short term, but that after around one plantation cycle the profits from mixed land use in the case study area are higher. Our paper shows that because of progressive soil subsidence, oil palm production cannot be maintained in peatlands in the medium and long term, even with currently promoted best management practices. This means that there is a need to stop the conversion of currently undrained peatlands and to restore degraded peatlands, in combination with policies that facilitate expansion of oil palm on mineral lands.

Responses to this article can be read online at: http://www.ecologyandsociety.org/issues/responses. $\mathrm{php} / 8490$

\section{Acknowledgments:}

We thankfully acknowledge the financial support of the European Research Council (Grant Agreement No. 263027) through the ECOSPACE project. We also thank two anonymous reviewers for their comments and suggestions.

\section{LITERATURE CITED}

Abram, N. K., P. Xofis, J. Tzanopoulos, D. C. MacMillan, M. Ancrenaz, R. Chung, L. Peter, R. Ong, I. Lackman, B. Goossens, L Ambu, and A. T. Knight. 2014. Synergies for improving oil palm production and forest conservation in floodplain landscapes. PLOS One 9(8):e106391. http://dx.doi.org/10.1371/ journal.pone.0095388

Agus, F., and I. G. M. Subiksa. 2008. Lahan gambut: potensi untuk pertanian dan aspek lingkungan [Peatland: its potential for agriculture and its environmental aspects]. Balai Penelitian Tanah [Soil Research Center] dan World Agroforestry Centre (ICRAF), Bogor, Indonesia.

Ahamad, M. S. S., R. Ali, N. A. Zakaria, A. A. Ghani, and C. K. Chang. 2009. Flood loss assessment of the 2003 Muda river flood. River 2011: Third International Conference on Managing Rivers in the 21st Century, Penang, Malaysia, 6-9 December 2009.

Andriesse, J. P. 1988. Nature and management of tropical peat soils. FAO Soils Bulletin 59:1-240.

Australia Indonesia Partnership. 2009. Kalimantan forests and climate partnership. Design document. [Online] URL: http:// 
formin.finland.fi $/$ public/download.aspx?ID $=48885 \&$ GUID $=\%$ 7B9B0BA3BA-25BF-4FEA-985B-B6DADCA60EAC\%7D

Barlow, C., Z. Zen, and R. Gondowarsito. 2003. The Indonesian oil palm industry. Oil Palm Industry Economic Journal 3(1):8-15.

Boer, R., D. R. Nurochmat, M. Ardiansyah, Hariyadi, H. Purwawangsa, and G. Ginting. 2012. Reducing agricultural expansion into forests in Central Kalimantan Indonesia: analysis of implementation and financing gaps. Center for Climate Risk and Opportunity Management, Bogor Agricultural University, Bogar, Indonesia.

Budiningsih, K., and R. Effendi. 2013. Financial analysis of Jelutung plantation in Central Kalimantan. Jurnal Penelitian Hutan Tanaman [Journal of Plantation Forest Research] 10 (1):17-23.

Casson, A., L. Tacconi, and K. Deddy. 2007. Strategies to reduce carbon emissions from the oil palm sector in Indonesia. Paper prepared for the Indonesian Forest Climate Alliance, Jakarta, Indonesia.

Central Kalimantan Estate Agency. 2012. FFB price in Central Kalimantan for period April-December 2012. Central Kalimantan Estate Agency, Kalimantan, Indonesia.

Colmer, T. D., and L. A. J. C. Voesenek. 2009. Flooding tolerance: suites of plant traits in variable environments. Functional Plant Biology 36:665-681. http://dx.doi.org/10.1071/FP09144

Couwenberg, J., R. Dommain, and H. Joosten. 2010. Greenhouse gas fluxes from tropical peatlands in South-east Asia. Global Change Biology 16:1715-1732. http://dx.doi.org/10.1111/

j.1365-2486.2009.02016.x

Couwenberg, J., and A. Hooijer. 2013. Towards robust subsidence-based soil carbon emission factors for peat soils in south-east Asia, with special reference to oil palm plantations. Mires and Peat 12(1):1-13.

Dewi, N. 2009. Responses of oil palm seedlings on inundation periods and complementary liquid fertilizers. Agrobis 1 (1):117-129.

Deltares. 2015. Flooding projections from elevation and subsidence models for oil palm plantations the Rajang Delta peatlands, Sarawak, Malaysia. Delatres Report 1207384. Deltares, Delft, Netherlands.

Department of Irrigation and Drainage (DID) Sarawak. 2001. Water management guidelines for agricultural development in lowland peat swamps of Sarawa. Report of the Department of Irrigation and Drainage, Sarawak, Malaysia.

Euroconsult Mott MacDonald and Deltares. 2008. Master plan for the rehabilitation and revitalisation of the ex-mega rice project area in Central Kalimantan: summary of main synthesis report. Deltares, Delft, Netherlands.

Fairhurst, T., and D. McLaughlin. 2009. Sustainable oil palm development on degraded land in Kalimantan. World Wildlife Fund, Washington, D.C. [online] URL: http://tropcropconsult. com/downloads files/Fairhurst2009.pdf

Farmer, J., R. Matthews, P. Smith, and J. U. Smith. 2014. The tropical peatland plantation-carbon assessment tool: estimating
$\mathrm{CO} 2$ emissions from tropical peat soils under plantations. Mitigation and Adaptation Strategies for Global Change 19 (6):863-885. http://dx.doi.org/10.1007/s11027-013-9517-4

Feintrenie, L., W. K. Chong, and P. Levang. 2010. Why do farmers prefer oil palm? Lessons learnt from Bungo District, Indonesia. Small-Scale Forestry 9:379-396. http://dx.doi.org/10.1007/ s11842-010-9122-2

Fuller, D. O., T. C. Jessup, and A. Salim, 2004. Loss of forest cover in Kalimantan, Indonesia, since the 1997-1998 El Niño. Conservation Biology 18(1):249-254. http://dx.doi.org/10.1111/ j.1523-1739.2004.00018.X

Gambolati, G., M. Putti, P. Teatini, and G. G. Stori. 2006. Subsidence due to peat oxidation and impact on drainage infrastructures in a farmland catchment south of the Venice Lagoon. Environmental Geology 49(6):814-820. http://dx.doi. org/10.1007/s00254-006-0176-6

Germer, J., and J. Sauerborn. 2008. Estimation of the impact of oil palm plantation establishment on greenhouse gas balance. Environment, Development and Sustainability 10:697-716. http:// dx.doi.org/10.1007/s10668-006-9080-1

Gunarso, P., M. E. Hartoyo, F. Agus, and T. J. Killeen. 2013. Oil palm and land use change in Indonesia, Malaysia and Papua New Guinea. Reports from the Technical Panels of the 2nd Greenhouse Gas Working Group of the Roundtable on Sustainable Palm Oil (RSPO). RSPO, Kuala Lumpur, Malaysia.

Hai, T. C., A. Ng, C. Prudente, C. Pang, and J. T. C Yee. 2001. Balancing the need for sustainable oil palm development and conservation: the lower Kinabatangan floodplains experience. ISP National Seminar 2001: Strategic Directions for the Sustainability of the Oil Palm Industry. Kota Kinabalu, Sabah, Malaysia.

Harun, M. K. 2011. Development of jelutung agroforestry for rehabilitation of degraded peatland in Central Kalimantan. Bogor Agricultural University, Bogor, West Java, Indonesia.

He, J., B. Zielinska, and R. Balasubramanian. 2010. Composition of semi-volatile organic compounds in the urban atmosphere of Singapore: influence of biomass burning. Atmospheric Chemistry and Physics 10:11401-11413. http://dx.doi.org/10.5194/acp-10-11401-2010

Hodgson, M. E., and P. Bresnaham. 2006. Accuracy of airborne Lidar-derived elevation. Photogrammetric Engineering \& Remote Sensing 3:331-339. http://dx.doi.org/10.14358/PERS.70.3.331

Holidi, H., and D. Irawanto. 2014. Growth of palm oil (Elaeis guineensis Jacq.) seedlings on peat soil in various water tables. Proceedings of National Conference on Sub-optimal Lands 2014. Palembang 26-27 September 2014. National Conference on Suboptimal Lands, Palembang, Indonesia.

Hooijer, A., S. Page, J. Jauhiainen, W. A. Lee, X. X. Lu, A. Idris, and G. Anshari. 2012. Subsidence and carbon loss in drained tropical peatlands. Biogeosciences 9(3):1053-1071. http://dx.doi. org/10.5194/bg-9-1053-2012

Hooijer, A., S. Page, P. Navratil, R. Vernimmen, M. van der Vat, K. Tansey, K. Konecny, F. Siegert, U. Ballhorn, and N. Mawdsley. 2014. Carbon emissions from drained and degraded peatland in Indonesia and emission factors for measurement, reporting and verification $(M R V)$ of peatland greenhouse gas emissions-a 
summary of KFCP research results for practitioners. IAFCP, Jakarta, Indonesia.

Ichsan, N., R. Vernimmen, A. Hooijer, and G. Applegate. 2013. KFCP hydrology and peat monitoring methodology. IAFCP, Jakarta, Indonesia.

Kalimantan-news. 2011. Harga TBS sawit capai tingkat tertinggi [FFB price reaches the highest level]. 6 January. Kalimantannews, Sintang, Kalimantan Barat, Indonesia.

Leifeld, J., M.öller, and J. Fuhrer. 2011. Peatland subsidence and carbon loss from drained temperate fens. Soil Use and Management 2:170-176. http://dx.doi.org/10.1111/j.1475-2743.2011.00327. $\underline{\mathrm{x}}$

Lim, K. H., S. S. Lim, F. Parish, and R. Suharto, editors. 2012. RSPO manual on best management practices (BMPs) for existing oil palm cultivation on peat. RSPO, Kuala Lumpur, Malaysia.

Liu, X. 2008. Airborne LiDAR for DEM generation: some critical issues. Progress in Physical Geography 32(1):31-49. http://dx.doi. org/10.1177/0309133308089496

Louck, D. P., E. van Beek, J. R. Stedinger, J. P. M. Dijkman, and M. T. Villars. 2005. Water resources systems planning and management: an introduction to methods, models and applications. UNESCO, Paris, France.

Miettinen J, C. Shi, W. J. Tan, and S. C. Liew. 2012. 2010 land cover map of insular South-east Asia in $250 \mathrm{~m}$ spatial resolution. Remote Sensing Letters 3:11-20. http://dx.doi.org/10.1080/0143$\underline{1161.2010 .526971}$

Ministry of Agriculture. 2009. Guidance for oil palm development on peatlands. Regulation of Minister of Agriculture No. 14. Ministry of Agriculture, Jakarta, Indonesia.

Ministry of Agriculture. 2011. Indonesian sustainable palm oil (ISPO). Regulation of Minister of Agriculture No. 19. Ministry of Agriculture, Jakarta, Indonesia.

Mondeel, H., and H. S. Budinetro. 2010. The Banger polder in Semarang. Center for River Basin Organizations and Management, Solo, Indonesia.

Moore, S., C. D. Evans, S. E. Page, M. H. Garnett, T. G. Jones, C. Freeman, A. Hooijer, A. J. Witshire, S. H. Limin, and V. Gauci. 2013. Deep instability of deforested tropical peatlands revealed by fluvial organic carbon fluxes. Nature 493:660-664. http://dx. doi.org/10.1038/nature11818

Morita, M. 2008. Flood risk analysis for determining optimal flood protection levels in urban river management. Journal of Flood Risk Management 1:142-149. http://dx.doi.org/10.1111/ j.1753-318X.2008.00016.X

Murdiyarso, D., S. Dewi, D. Lawrence, and F. Seymour. 2011. Indonesia's forest moratorium: a stepping stone to better forest governance? Working Paper 76. CIFOR, Bogor, Indonesia.

Nurida, N. L., A. Mulyani, and F. Agus, editors. 2011. Pengelolaan lahan gambut berkelanjutan [Sustainable peatland management]. Soil Research Center, Bogor, Indonesia.

Obidzinski, K., R. Andriani, H. Komarudin, and A. Andrianto. 2012. Environmental and social impacts of oil palm plantations and their implications for biofuel production in Indonesia. Ecology and Society 17(1):25. http://dx.doi.org/10.5751/ ES-04775-170125

Page, S. E., and C. Banks. 2007. Tropical peatlands: distribution, extent and carbon storage - uncertainties and knowledge gaps. Peatlands International 2:26-27.

Poesie, E. S., T. Shimamura, S. E. Page, I. Ninomiya, and S. H. Limin. 2011. Species composition and phylogenetic diversity in a tropical peat swamp forest, Central Kalimantan, Indonesia. Tropics 19(2):93-105. http://dx.doi.org/10.3759/tropics.19.93

Posa, M. R. C., L. S. Wijedasa, and R. T. Corlett. 2011. Biodiversity and conservation of tropical peat swamp forest. BioScience 61:49-57. http://dx.doi.org/10.1525/bio.2011.61.1.10

Pronger, J., L. A. Schipper, R. B. Hill, D. I. Campbell, and M. McLeod. 2014. Subsidence rates of drained agricultural peatlands in New Zealand and the relationship with time since drainage. Journal of Environmental Quality 43:1442-1449. http://dx.doi. org/10.2134/jeq2013.12.0505

Republic of Indonesia. 2011. New licensing moratorium and management improvement of primary forests and peatlands. Indonesian Presidential Instruction No. 10. Republic of Indonesia, Jakarta, Indonesia.

Republic of Indonesia. 2013. New licensing moratorium and management improvement of primary forests and peatlands. Indonesian Presidential Instruction No. 6. Republic of Indonesia, Jakarta, Indonesia.

Republic of Indonesia. 2015. New licensing moratorium and management improvement of primary forests and peatlands. Indonesian Presidential Instruction No. 8. Republic of Indonesia, Jakarta, Indonesia.

Roggeri, H. 1995. Tropical freshwater wetlands. Springer, Dordrecht, the Netherlands. http://dx.doi.org/10.1007/978-94-015-8398-5

Sabari, N. S., S. Harun, and A. Ahmad. 2014. The effect of flood hazard on palm oil yield in Sungai Simpang Kiri Estate. The 13th International Conference on Urban Drainage. Sarawak, Malaysia, 7-12 September 2014.

Schrier-Uijl, A. P., M. Silvius, F. Parish, K. H. Lim, S. Rosediana, and G. Anshari. 2013. Environmental and social impacts of oil palm cultivation on tropical peat - a scientific review. RSPO, Kuala Lumpur, Malaysia.

Sheil, D., A. Casson, E. Meijaard, M. van Nordwijk, J. Gaskell, J. Sunderland-Groves, K. Wertz, and M. Kanninen. 2009. The impacts and opportunities of oil palm in Southeast Asia: what do we know and what do we need to know? Occasional paper no. 51. CIFOR, Bogor, Indonesia.

Smit, H. H., E. Meijaard, C. van der Laan, S. Mantel, A Budiman, and P. Verweij. 2013. Breaking the link between environmental degradation and oil palm expansion: a method for enabling sustainable oil palm expansion. PLOS ONE 8(9):e68610. http://dx.doi.org/10.1371/journal.pone.0068610

Sumarga, E., and L. Hein. 2014. Mapping ecosystem services for land use planning. Environmental Management 54(1):84-97. http://dx.doi.org/10.1007/s00267-014-0282-2 
Sumarga, E., and L. Hein. 2016. Benefits and costs of oil palm expansion in Central Kalimantan, Indonesia, under different policy scenarios. Regional Environmental Change 16(4):1011-1021. http://dx.doi.org/10.1007/s10113-015-0815-0

Sumarga, E., L. Hein, B. Eden, and A. Suwarno. 2015. Mapping monetary values of ecosystem services in support of developing ecosystem accounts. Ecosystem Services 12:71-83. http://dx.doi. org/10.1016/j.ecoser.2015.02.009

Suzuki, S., T. Ishida, T. Nagano, and S. Waijaroen. 1999. Influences of deforestation on carbon balance in a natural tropical peat swamp forest in Thailand. Environmental Control in Biology 37:115-128. http://dx.doi.org/10.2525/ecb1963.37.115

United States Environmental Protection Agency. 2013. The social cost of carbon. United States Environmental Protection Agency, Washington, D.C., USA. [online] URL: http://www.epa.gov/ climatechange/EPAactivities/economics/scc.html

van der Meer, P., and B. F. Ibie. 2009. Master plan for the conservation and development of the ex-mega rice project area in Central Kalimantan. Euroconsult Mott Macdonald. Deltares, Delft, Netherlands.

van Wijk, C. L. 1950. Some notes on artificial regeneration of Jelutong (D. lowii). Tectona 40(2):167-173.

Varkkey, H. 2013. Oil palm plantations and transboundary haze: patronage networks and land licensing in Indonesia's peatlands. Wetlands 33(4):679-690. http://dx.doi.org/10.1007/s13157-013-0423-

$\underline{z}$

Wahyunto, S. Ritung, and H. Subagjo. 2004. Peta sebaran lahan gambut, luas dan kandungan karbon di Kalimantan/Map of peatland distribution area and carbon content in Kalimantan, 2000-2002. Wetlands International-Indonesia Programme \& Wildlife Habitat Canada, Bogor, Indonesia.

Wich, S. A., E. Meijaard, A. J. Marshall, S. Husson, M. Ancrenaza, R. C. Lacy, C. P. van Schaika, J. Sugardjitoa, T. Simorangkira, K. Traylor-Holzera, et al. 2008. Distribution and conservation status of the orang-utan (Pongo spp.) on Borneo and Sumatra: how many remain? Oryx 42:329-339. http://dx.doi. org/10.1017/S003060530800197X

Wösten, J. H. M., A. B. Ismail, and A. L .M. van Wijk. 1997. Peat subsidence and its practical implications: a case study in Malaysia. Geoderma 78:25-36. http://dx.doi.org/10.1016/S0016-7061(97) $\underline{00013-X}$

Yule, C. M. 2010. Loss of biodiversity and ecosystem functioning in Indo-Malayan peat swamp forests. Biodiversity and Conservation 19(2):393-409. http://dx.doi.org/10.1007/s10531-008-9510-5 
Appendix 1. Net Present Value (NPV) calculations

Table A 1.1. NPV of fresh fruit brunch (FFB) production in mineral soil, modified from Fairhurst and McLaughlin (2009) with a discount rate of $10 \%$ and FFB price of $€ 130 /$ ton, values are rounded.

\begin{tabular}{|c|c|c|c|c|c|c|c|c|c|c|c|c|c|c|c|c|c|c|c|c|c|c|c|}
\hline Year & & 0 & 1 & 2 & 3 & 4 & 5 & 6 & 7 & 8 & 9 & 10 & 11 & 12 & 13 & 14 & 15 & 16 & 17 & 18 & 19 & 20 & NPV \\
\hline FFB yield & ton/ha & 0 & 0 & 0 & 5 & 10 & 15 & 20 & 24 & 26 & 27 & 27 & 27 & 27 & 27 & 27 & 27 & 26 & 25 & 24 & 23 & 22 & \\
\hline FFB price & $€ /$ ton & 130 & 130 & 130 & 130 & 130 & 130 & 130 & 130 & 130 & 130 & 130 & 130 & 130 & 130 & 130 & 130 & 130 & 130 & 130 & 130 & 130 & \\
\hline $\begin{array}{l}\text { Gross } \\
\text { revenue }\end{array}$ & $€ /$ ha & 0 & 0 & 0 & 650 & 1300 & 1950 & 2600 & 3120 & 3380 & 3510 & 3510 & 3510 & 3510 & 3510 & 3510 & 3445 & 3380 & 3250 & 3120 & 2990 & 2860 & \\
\hline $\begin{array}{l}\text { Planting and } \\
\text { other } \\
\text { farming } \\
\text { costs }\end{array}$ & $€ /$ ha & 1083 & 1094 & 701 & 1246 & 729 & 729 & 729 & 729 & 729 & 729 & 729 & 729 & 729 & 729 & 729 & 729 & 729 & 729 & 729 & 729 & 729 & \\
\hline $\begin{array}{l}\text { Land lease } \\
\text { costs }\end{array}$ & $€ / \mathrm{ha}$ & 342 & 0 & 0 & 0 & 0 & 0 & 0 & 0 & 0 & 0 & 0 & 0 & 0 & 0 & 0 & 0 & 0 & 0 & 0 & 0 & 0 & \\
\hline $\begin{array}{l}\text { Harvesting } \\
\text { costs }\end{array}$ & $€ /$ ha & 0 & 0 & 0 & 38 & 76 & 114 & 152 & 183 & 198 & 205 & 205 & 205 & 205 & 205 & 205 & 202 & 198 & 190 & 183 & 175 & 167 & \\
\hline $\begin{array}{l}\text { Depreciation } \\
\text { cost }\end{array}$ & $€ /$ ha & 0 & 0 & 0 & 47 & 94 & 94 & 94 & 94 & 94 & 94 & 94 & 94 & 94 & 94 & 94 & 94 & 94 & 94 & 94 & 94 & 94 & \\
\hline $\begin{array}{l}\text { Costs of } \\
\text { fixed assets }\end{array}$ & $€ /$ ha & 0 & 0 & 0 & 165 & 160 & 151 & 141 & 132 & 122 & 113 & 104 & 94 & 85 & 75 & 66 & 56 & 47 & 38 & 28 & 19 & 9 & \\
\hline Total costs & $€ /$ ha & 1425 & 1094 & 701 & 1496 & 1060 & 1088 & 1117 & 1138 & 1144 & 1142 & 1132 & 1123 & 1114 & 1104 & 1095 & 1082 & 1068 & 1051 & 1034 & 1017 & 1000 & \\
\hline Net benefit & $€ / \mathrm{ha}$ & -1425 & -1094 & -701 & -846 & 240 & 862 & 1483 & 1982 & 2236 & 2368 & 2378 & 2387 & 2396 & 2406 & 2415 & 2363 & 2312 & 2199 & 2086 & 1973 & 1860 & \\
\hline PV & $€ /$ ha & -1425 & -995 & -579 & -635 & 164 & 535 & 837 & 1017 & 1043 & 1004 & 917 & 837 & 764 & 697 & 636 & 566 & 503 & 435 & 375 & 323 & 276 & 7294 \\
\hline
\end{tabular}

Note: This NPV applies for oil palm production in the period of 2011, after 25 years and after 50 years 
Table A 1.2. NPV of FFB production on peat soil with no flooding problems, modified from Fairhurst and McLaughlin (2009) and FFB price of $€ 130 /$ ton with a discount rate of $10 \%$, values are rounded.

\begin{tabular}{|c|c|c|c|c|c|c|c|c|c|c|c|c|c|c|c|c|c|c|c|c|c|c|c|}
\hline Year & & 0 & 1 & 2 & 3 & 4 & 5 & 6 & 7 & 8 & 9 & 10 & 11 & 12 & 13 & 14 & 15 & 16 & 17 & 18 & 19 & 20 & NPV \\
\hline FFB yield & ton/ha & 0 & 0 & 0 & 5 & 10 & 15 & 20 & 24 & 26 & 27 & 27 & 27 & 27 & 27 & 27 & 27 & 26 & 25 & 24 & 23 & 22 & \\
\hline FFB price & $€ /$ ton & 130 & 130 & 130 & 130 & 130 & 130 & 130 & 130 & 130 & 130 & 130 & 130 & 130 & 130 & 130 & 130 & 130 & 130 & 130 & 130 & 130 & \\
\hline Revenue & $€ / \mathrm{ha}$ & 0 & 0 & 0 & 650 & 1300 & 1950 & 2600 & 3120 & 3380 & 3510 & 3510 & 3510 & 3510 & 3510 & 3510 & 3445 & 3380 & 3250 & 3120 & 2990 & 2860 & \\
\hline $\begin{array}{l}\text { Planting, } \\
\text { drainage and } \\
\text { other farming } \\
\text { costs }\end{array}$ & $€ / \mathrm{ha}$ & 1082 & 2018 & 700 & 1245 & 729 & 729 & 729 & 729 & 729 & 729 & 729 & 729 & 729 & 729 & 729 & 729 & 729 & 729 & 729 & 729 & 729 & \\
\hline $\begin{array}{l}\text { Land lease } \\
\text { costs }\end{array}$ & $€ / \mathrm{ha}$ & 342 & 0 & 0 & 0 & 0 & 0 & 0 & 0 & 0 & 0 & 0 & 0 & 0 & 0 & 0 & 0 & 0 & 0 & 0 & 0 & 0 & \\
\hline $\begin{array}{l}\text { Harvesting } \\
\text { and } \\
\text { transportation } \\
\text { costs }\end{array}$ & $€ / \mathrm{ha}$ & 0 & 0 & 0 & 38 & 76 & 114 & 152 & 182 & 198 & 205 & 205 & 205 & 205 & 205 & 205 & 201 & 198 & 190 & 182 & 175 & 167 & \\
\hline $\begin{array}{l}\text { Depreciation } \\
\text { cost }\end{array}$ & $€ / \mathrm{ha}$ & 0 & 0 & 0 & 94 & 188 & 188 & 188 & 188 & 188 & 188 & 188 & 188 & 188 & 188 & 188 & 188 & 188 & 188 & 188 & 188 & 188 & \\
\hline $\begin{array}{l}\text { Costs of } \\
\text { fixed assets }\end{array}$ & $€ / \mathrm{ha}$ & 0 & 0 & 0 & 329 & 320 & 301 & 282 & 263 & 245 & 226 & 207 & 188 & 169 & 150 & 132 & 113 & 94 & 75 & 56 & 38 & 19 & \\
\hline Total costs & $€ /$ ha & 1424 & 2018 & 700 & 1706 & 1313 & 1332 & 1351 & 1362 & 1359 & 1348 & 1329 & 1310 & 1291 & 1272 & 1254 & 1231 & 1208 & 1182 & 1156 & 1129 & 1103 & \\
\hline Net benefit & $€ / \mathrm{ha}$ & -1424 & -2018 & -700 & $\begin{array}{r}- \\
1056\end{array}$ & -13 & 618 & 1249 & 1758 & 2021 & 2162 & 2181 & 2200 & 2219 & 2238 & 2256 & 2214 & 2172 & 2068 & 1964 & 1861 & 1757 & \\
\hline PV & $€ / \mathrm{ha}$ & -1424 & -1834 & -579 & -793 & -9 & 384 & 705 & 902 & 943 & 917 & 841 & 771 & 707 & 648 & 594 & 530 & 473 & 409 & 353 & 304 & 261 & 5104 \\
\hline
\end{tabular}

Note: This NPV applies for oil palm production in the period of 2011, after 25 years and after 50 years 
Table A 1.3. NPVs of FFB production under increasing flood risks within a plantation cycle in the period of 2011, after 25 years and after 50 years.

\begin{tabular}{|c|c|c|c|c|c|c|c|c|c|c|c|c|c|c|c|c|c|c|c|c|c|}
\hline $\begin{array}{l}\text { Number of years (no } \\
\text { flooding - impaired } \\
\text { drainability) }\end{array}$ & $21-0$ & $20-1$ & $19-2$ & $18-3$ & $17-4$ & $16-5$ & $15-6$ & $14-7$ & $13-8$ & $12-9$ & $11-10$ & $10-11$ & $9-12$ & $8-13$ & $7-14$ & 6-15 & $5-16$ & $4-17$ & $3-18$ & $2-19$ & $1-20$ \\
\hline NPV (€/ha) & 5104 & 4998 & 4875 & 4735 & 4574 & 4390 & 4184 & 3953 & 3699 & 3419 & 3112 & 2773 & 2401 & 2007 & 1607 & 1240 & 937 & 715 & 593 & 593 & 593 \\
\hline $\begin{array}{l}\text { Number of years } \\
\text { (impaired drainability } \\
\text { - prolonged flooding) }\end{array}$ & $21-0$ & $20-1$ & $19-2$ & $18-3$ & \begin{tabular}{ll|}
$17-4$ \\
\end{tabular} & $16-5$ & $15-6$ & 14-7 & $13-8$ & $12-9$ & $11-10$ & $10-11$ & $9-12$ & $8-13$ & $7-14$ & 6-15 & 5-16 & 4-17 & 3-18 & $2-19$ & $1-20$ \\
\hline NPV (€/ha) & 593 & 487 & 365 & 224 & 64 & 0 & 0 & 0 & 0 & 0 & 0 & 0 & 0 & 0 & 0 & 0 & 0 & 0 & 0 & 0 & 0 \\
\hline $\begin{array}{l}\text { Number of years } \\
\text { (prolonged flooding - } \\
\text { near-permanent } \\
\text { inundation) }\end{array}$ & $21-0$ & $20-1$ & $19-2$ & $18-3$ & $17-4$ & $16-5$ & $15-6$ & 14-7 & 13-8 & $12-9$ & 11-10 & $10-11$ & $9-12$ & $8-13$ & $7-14$ & $6-15$ & $5-16$ & $4-17$ & 3-18 & $2-19$ & $1-20$ \\
\hline NPV (€/ha) & 0 & 0 & 0 & 0 & 0 & 0 & 0 & 0 & 0 & 0 & 0 & 0 & 0 & 0 & 0 & 0 & 0 & 0 & 0 & 0 & 0 \\
\hline
\end{tabular}

Note: Given the assumptions on subsidence rate and drainage levels used in this study, the maximum peat subsidence in a plantation cycle is about $70 \mathrm{~cm}$, hence an area will

experience maximum two flood risks (no flooding - impaired drainability, impaired drainability - prolonged flooding, or prolonged flooding - near-permanent inundation). 
Table A 1.4. NPV of Jelutung production (€/ha), modified from Harun (2011) with a discount rate of $10 \%$, values are rounded.

\begin{tabular}{|c|c|c|c|c|c|c|c|c|c|c|c|c|c|c|c|c|}
\hline & 0 & 1 & 2 & 3 & 4 & 5 & 6 & 7 & 8 & 9 & 10 & 11 & 12 & 13 & 14 & 15 \\
\hline Revenue & 0 & 0 & 0 & 0 & 0 & 0 & 0 & 0 & 0 & 0 & 56 & 56 & 101 & 101 & 182 & 182 \\
\hline Equipments and inputs & 0 & 102 & 125 & 163 & 142 & 131 & 125 & 125 & 135 & 125 & 190 & 128 & 167 & 128 & 157 & 128 \\
\hline Land lease costs & 342 & 0 & 0 & 0 & 0 & 0 & 0 & 0 & 0 & 0 & 0 & 0 & 0 & 0 & 0 & 0 \\
\hline Land preparation costs & 127 & 364 & 0 & 0 & 0 & 0 & 0 & 0 & 0 & 0 & 0 & 0 & 0 & 0 & 0 & 0 \\
\hline Planting & 0 & 50 & 10 & 0 & 0 & 0 & 0 & 0 & 0 & 0 & 0 & 0 & 0 & 0 & 0 & 0 \\
\hline Plant maintenance & 0 & 18 & 18 & 18 & 18 & 18 & 68 & 309 & 18 & 18 & 18 & 13 & 63 & 304 & 13 & 13 \\
\hline Total costs & 469 & 534 & 153 & 180 & 159 & 149 & 193 & 434 & 153 & 143 & 207 & 140 & 230 & 432 & 169 & 140 \\
\hline Net value & -469 & -534 & -153 & -180 & -159 & -149 & -193 & -434 & -153 & -143 & -151 & -84 & -128 & -330 & 13 & 42 \\
\hline PV & -469 & -485 & -126 & -135 & -109 & -92 & -109 & -223 & -71 & -60 & -58 & -29 & -41 & -96 & 3 & 10 \\
\hline
\end{tabular}

\begin{tabular}{|c|c|c|c|c|c|c|c|c|c|c|c|c|c|c|c|c|}
\hline & 16 & 17 & 18 & 19 & 20 & 21 & 22 & 23 & 24 & 25 & 26 & 27 & 28 & 29 & 30 & NPV \\
\hline Revenue & 328 & 328 & 590 & 590 & 1063 & 1063 & 1913 & 1913 & 3444 & 3444 & 6199 & 6199 & 11158 & 11158 & 35834 & \\
\hline Equipments and inputs & 167 & 128 & 157 & 128 & 196 & 128 & 157 & 128 & 167 & 128 & 157 & 128 & 167 & 128 & 159 & \\
\hline Land lease costs & 342 & 0 & 0 & 0 & 0 & 0 & 0 & 0 & 0 & 0 & 0 & 0 & 0 & 0 & 0 & \\
\hline Land preparation & 0 & 0 & 0 & 0 & 0 & 0 & 0 & 0 & 0 & 0 & 0 & 0 & 0 & 0 & 0 & \\
\hline Planting & 0 & 0 & 0 & 0 & 0 & 0 & 0 & 0 & 0 & 0 & 0 & 0 & 0 & 0 & 0 & \\
\hline Plant maintenance & 13 & 13 & 63 & 13 & 13 & 13 & 13 & 13 & 13 & 13 & 13 & 13 & 13 & 13 & 13 & \\
\hline Total costs & 180 & 140 & 219 & 140 & 209 & 140 & 169 & 140 & 180 & 140 & 169 & 140 & 180 & 140 & 172 & \\
\hline Net value & 148 & 188 & 371 & 450 & 854 & 923 & 1744 & 1773 & 3264 & 3304 & 6030 & 6059 & 10978 & 11018 & 35662 & \\
\hline PV & 32 & 37 & 67 & 74 & 127 & 125 & 214 & 198 & 331 & 305 & 506 & 462 & 761 & 695 & 2044 & 3887 \\
\hline
\end{tabular}


Table A 1.5. NPVs of carbon sequestration (€/ha), values are rounded.

\begin{tabular}{|c|c|c|c|c|c|c|c|c|c|c|c|c|c|c|c|c|c|c|c|c|c|c|}
\hline Year & 0 & 1 & 2 & 3 & 4 & 5 & 6 & 7 & 8 & 9 & 10 & 11 & 12 & 13 & 14 & 15 & 16 & 17 & 18 & 19 & 20 & NPV \\
\hline $\begin{array}{l}\text { carbon sequestration of } \\
\text { oil palm in mineral soil } \\
\text { (ton C/ha/year) }\end{array}$ & 2 & 2 & 2 & 2 & 2 & 2 & 2 & 2 & 2 & 2 & 2 & 2 & 2 & 2 & 2 & 2 & 2 & 2 & 2 & 2 & 2 & \\
\hline $\mathrm{SCC}(€ /$ ton $\mathrm{C})$ & 103 & 103 & 103 & 103 & 103 & 103 & 103 & 103 & 103 & 103 & 103 & 103 & 103 & 103 & 103 & 103 & 103 & 103 & 103 & 103 & 103 & \\
\hline $\begin{array}{l}\text { Value of carbon } \\
\text { sequestration } \\
(€ / \text { ha/year) }\end{array}$ & 196 & 196 & 196 & 196 & 196 & 196 & 196 & 196 & 196 & 196 & 196 & 196 & 196 & 196 & 196 & 196 & 196 & 196 & 196 & 196 & 196 & \\
\hline $\mathrm{PV}(€ / \mathrm{ha})$ & 196 & 178 & 162 & 147 & 134 & 122 & 110 & 100 & 91 & 83 & 75 & 69 & 62 & 57 & 52 & 47 & 43 & 39 & 35 & 32 & 29 & 1862 \\
\hline & & & & & & & & & & & & & & & & & & & & & & \\
\hline $\begin{array}{l}\text { carbon sequestration of } \\
\text { oil palm on peat (ton } \\
\text { C/ha/year) }\end{array}$ & -15 & -15 & -15 & -15 & -15 & -15 & -15 & -15 & -15 & -15 & -15 & -15 & -15 & -15 & -15 & -15 & -15 & -15 & -15 & -15 & -15 & \\
\hline $\mathrm{SCC}(€ /$ ton $\mathrm{C})$ & 103 & 103 & 103 & 103 & 103 & 103 & 103 & 103 & 103 & 103 & 103 & 103 & 103 & 103 & 103 & 103 & 103 & 103 & 103 & 103 & 103 & \\
\hline $\begin{array}{l}\text { Value of carbon } \\
\text { sequestration } \\
(€ / \text { ha/year) } \\
\end{array}$ & -1545 & -1545 & -1545 & -1545 & -1545 & -1545 & -1545 & -1545 & -1545 & -1545 & -1545 & -1545 & -1545 & -1545 & -1545 & -1545 & -1545 & -1545 & -1545 & -1545 & -1545 & \\
\hline $\mathrm{PV}(€ / \mathrm{ha})$ & -1545 & -1405 & -1277 & -1161 & -1055 & -959 & -872 & -793 & -721 & -655 & -596 & -542 & -492 & -448 & -407 & -370 & -336 & -306 & -278 & -253 & -230 & -14698 \\
\hline & & & & & & & & & & & & & & & & & & & & & & \\
\hline $\begin{array}{l}\text { carbon sequestration of } \\
\text { peat forest and Jelutung } \\
\text { forest (ton C/ha/year) }\end{array}$ & 5 & 5 & 5 & 5 & 5 & 5 & 5 & 5 & 5 & 5 & 5 & 5 & 5 & 5 & 5 & 5 & 5 & 5 & 5 & 5 & 5 & \\
\hline SCC $(€ /$ ton $\mathrm{C})$ & 103 & 103 & 103 & 103 & 103 & 103 & 103 & 103 & 103 & 103 & 103 & 103 & 103 & 103 & 103 & 103 & 103 & 103 & 103 & 103 & 103 & \\
\hline $\begin{array}{l}\text { Value of carbon } \\
\text { sequestration } \\
(€ / \text { ha/year }) \\
\end{array}$ & 546 & 546 & 546 & 546 & 546 & 546 & 546 & 546 & 546 & 546 & 546 & 546 & 546 & 546 & 546 & 546 & 546 & 546 & 546 & 546 & 546 & \\
\hline $\mathrm{PV}(€ / \mathrm{ha})$ & 546 & 496 & 451 & 410 & 373 & 339 & 308 & 280 & 255 & 232 & 210 & 191 & 174 & 158 & 144 & 131 & 119 & 108 & 98 & 89 & 81 & 5193 \\
\hline
\end{tabular}


Table A 1.6. Total NPV of FFB production under increasing flood risks in the first plantation cycle of the 'OP' scenario.

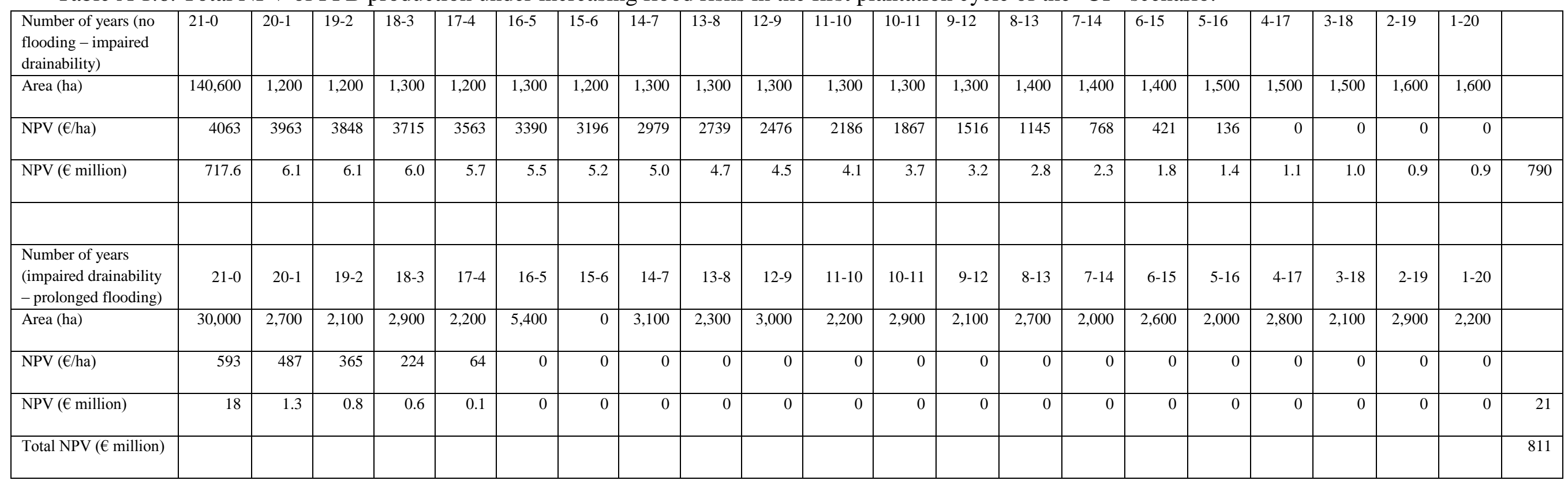

